\title{
Methodology for bilingual recommendation, Spanish- English, of literary texts in a high school language
} resource center

\begin{abstract}
This research is part of a descriptive study of bilingual, Spanish-English, writing for recommending literary texts in high school level at Escuela Nacional Preparatoria in Mexico City. The purpose is specifying a methodology to promote bilingual written production of six students in a workshop in the language resource center, by means of multiple printed, digital and online resources. It includes counseling, writing agreements and a blog with sections for revision, feedback, text editing, as well as manuals and questionnaires for consulting, translating and language usages. Emphasis was focused on activities to promote students' self-regulation on performance and reflection on bilingual writing. Results include considerations, preferences, and the ways to deal with difficulties, mainly, decontextualized practices with translators and text processors. Benefits and limitations of this methodology are considered for personal and online consulting, multimedia resources, interactions and possible adaptations of the proposal.
\end{abstract}

Keywords: bilingual writing, intertextuality, online interactivity, high school, multimedia resources, counseling
Volume 3 Issue 3 - 2019

\author{
Ernesto Hernández Rodríguez \\ Universidad Nacional Autónoma de México, Mexico
}

Correspondence: Ernesto Hernández Rodríguez, Universidad Nacional Autónoma de México, Emiliano Zapata 18, Guadalupe Victoria Cuautepec 07209, Ciudad de México, Mexico, Tel 0445527454505, Email ernestotem@live.com.mx

Received: May 23, 2019| Published: June 13, 2019

\section{Introduction}

Students in high school need to write bilingual academic texts for different purposes and communicative functions. It is common that they have not developed knowledge or skills required for this type of writing. For this reason, they request support in bilingual writing in academic texts, and also for personal communication in letters and in social networks. Bilingual writing is a source of controversy since the lack of interrelation between native and foreign languages is generally promoted, as well as the idea that translation harms or interferes language teaching. In contrast, Pegenaute ${ }^{1}$, Nord $^{2}$ and Fredholm ${ }^{3}$ propose translation as a support for language learning. In bilingual recommendation, students carry out self-translation of their texts, with the possibility of rewriting them in both languages, in order to adjust writing through multiple resources. ${ }^{4}$ Popovič et al., ${ }^{5-8} \mathrm{Jung}^{9}$ contemplate self-translation as a topic of research, and they disagree with the idea that translation is an art only for experts.

This study focused on a methodology applied to bilingual writing with the support of resources offered by a high school language resource center that includes printed, digital and online multimedia materials. Students attended a workshop for bilingual recommendation of readings, with advice and activities to encourage reflection and regulation of performance in revision and editing practices. The activities included taking agreements on how to recommend literary texts, orientation in booklets about translation practices, language usages and reflections in a questionnaire. On this occasion, this research did not carry out the descriptive study of the drafted texts; the focus was on the general characterization and reflections on written performances, strategies and sources employed, as a result of a proposed methodological design. It is necessary to promote methodological applications for bilingual writing, with the support of printed, online and multimedia materials to take advantage of possibilities offered by these resources for learning.

The purpose of this research was to present the methodological elicitation procedures to encourage bilingual writing, Spanish-
English, in the recommendation of literary texts. In this way, it was possible to have access to representative samples of writing. Also, the teaching methodology involves counseling with the support of multimedia printed and online materials in the language resource center. In this workshop, online interaction was developed through a blog, as a means of accessing multiple materials for consultation, guidance on translation, language usages and reflections expressed in questionnaires. The emphasis in this paper focused exclusively on the methodological procedures.

\section{Methodology}

\section{Approach}

This research contemplates personal counseling and interaction in a blog that provides exercises, manuals and a menu of digital, online and printed materials. The purpose was that students could manage a diversity of language resources to develop bilingual writing. These practices implied digital intertextuality, feedback in personal and online counseling. We can find these conceptions in Whitman ${ }^{10}$, Coyle et al. ${ }^{11}$ and Mayer. ${ }^{12}$ Fabre-Cols ${ }^{13}$ and Macklin ${ }^{14}$ contemplate a dialogical interactivity approach in accompaniment for revision and reflexive textual edition. Likewise, digital reading allows diverse approaches to textuality discursive practices and access to information. ${ }^{15}$

A blog is a free internet tool with multimedia and hypertext capabilities with links to certain sources of textuality and information in these activities, dictionaries, translators, and grammar tools. It also allows registration of opinions, discussions, and feedback from other users. A blog is not limited to a site to publish or post texts; it can also be a forum to interact and discuss, so it is useful for counseling in writing tasks. In a blog we can use free access tools, for example, blogger, Google forms and online textual alternatives to organize and share information. García et al. ${ }^{16}$ Álvarez ${ }^{17}$ and Reyes Angona ${ }^{18}$ provide research perspectives about blogs as tools that involve multiple possibilities with applications to education. 
The methodology of elicitation in this paper consisted of techniques and strategies to encourage linguistic expression in writing, ${ }^{19,20}$ as well as reflections expressed by students in questionnaires about performances. This perspective of elicitation includes decisions to design activities, interactions and materials to try to obtain writing samples according to research in academic writing in multimedia contexts. As a teaching methodology, counseling activities focused on linguistic regulation, with the perspective of reflexive expectations in performance and intentionality in writing, revision and edition. Students' considerations about their writing processes involved textuality standards: cohesion, coherence, intentionality, informativity, situationality, acceptability and intertextuality. ${ }^{21}$

Cohesion is related to textual articulation due to the handling of grammar, syntax, connectors and punctuation. Coherence provides knowledge and abilities to express clear and understandable meanings. Intentionality corresponds to what the writer tries to express. Informativity exhibits contents. Situationality is the communicative context. Acceptability or adequacy is the assessment of language and intention in a given environment and intertextuality is the relationship established with other texts. These criteria are fundamental for counseling and feedback to write, revise, and edit texts with the intention to improve them.

This research conceives an approach of self-translation applied to revision and rewriting to achieve critical performance regulation, as well as promoting reflection and interrelation of mother and foreign languages in a dynamic translation perspective. ${ }^{22-23}$ Self-translation involves opportunities to assess, modify and improve written versions in native and foreign languages..$^{5-9}$ This paper considers performance reflections as a procedure to develop awareness in intentionality in self-translation practices ${ }^{29}$ when students assess their texts and try to improve them in the next version.

\section{Methodological design}

We held the workshop in February and March 2016 in 6 sessions of 50 minutes, with teenage students from Mexico City who attended the third grade Mexican literature course in the National Preparatory School of Universidad Nacional Autónoma de México. These students (Victoria, Oscar, Yadira, Mara, Miguel and Cassandra) were in a basic level of English as a foreign language, in reading comprehension and grammar, without the development of oral expression and written recommendation of texts. Due to this characterization of performance and the purposes of this workshop, centered on writing, the language of instruction and oral interaction was Spanish. In order to consider a variety of multimedia and online options, the methodological design was incorporated in a blog that facilitated access to collections of consultation sources and guidance manuals on language uses:

Cuadernillo de orientaciones para la redacción bilingüe Hernández Rodríguez ${ }^{4}$ Consult:

http://recomendacionesbilinguesmediateca.blogspot. com/?view=sidebar

The interaction included comments, reflections, written versions, feedback and questionnaires about activities carried out. In addition, the option to create databases in the blog was useful to obtain information from questionnaires for subsequent analysis of students' assessment of their written performances.

We started the workshop with an introductory session to orally comment on the importance of bilingual writing to recommend literary texts. Then, students expressed their points of view in the first questionnaire of the blog. Below we can see the questions.

\section{Bilingual recommendation of literary texts}

What can be the utility of recommending readings to those who attend the language resource center?

What can be the utility of recommending texts in a bilingual way? (Spanish-English)

In what situations can we find bilingual texts? Mention some.

The method to characterize responses was to relate them to students' drafting decisions and multimedia support resources in printed and online collections. In order to motivate students to write comments of a text, they read on a screen an illustrated basic story from the printed and online text collection:

"Nasreddin and the museum guide". ${ }^{25}$ Consult:

http://recomendacionesbilingues.blogspot.mx/2015/10/800x600normal-0-21-false-false-false_92.html

First, we emphasized reading comprehension and vocabulary. We also translated the content and commented it orally. Students considered how they could write a text to recommend the story. In the next activity, we negotiated agreements to writing recommendations of texts. Students commented on some criteria about this type of writing and reviewed considerations of other students from previous workshops. In the next section, they discussed a presentation about academic criteria to comment texts and, finally, they reached agreements about this kind of writing:

\section{Consider characteristics of a written recommendation of a text}

Present adequate information: the necessary, not to mention more or the end.

Mention data about reading: title, author, literary style.

Express a clear opinion, points of view

Take the reader into account: to approach him to attract his attention.

Present representative examples of the text to try to encourage readers.

Be brief and interesting.

Write a coherent and grammatically careful text.

Consult:

http://recomendacionesbilinguesmediateca.blogspot.mx/2015/11/ criterios-para-recomendar-una-lectura.html?view=sidebar

These criteria were useful for writing procedures. Thus, students reflected on textual organization, according to socialized agreements. Then, they wrote their views on how to write a bilingual recommendation of a text and the steps to follow. Students answered the following questions.

How would you write a bilingual recommendation of a text?

What steps would you follow?

In addition, we included in the blog a booklet of resources on bilingual writing to serve as a source of consultation during the writing process. 
Consult:

\section{https://www.flipsnack.com/ErnestoHernndezRodrguez/}

This material provides access and information about printed and online consultation sources, such as dictionaries, grammar texts, translators, and syntax and orthographic correctors in the Word processor software. The following Figure 1 presents an example of the organization of this information in a menu format. Each source is associated with a hyperlink to access query options in native and foreign languages. Next, students read and commented on the "Booklet of guidelines on translation and language usage" in the blog.

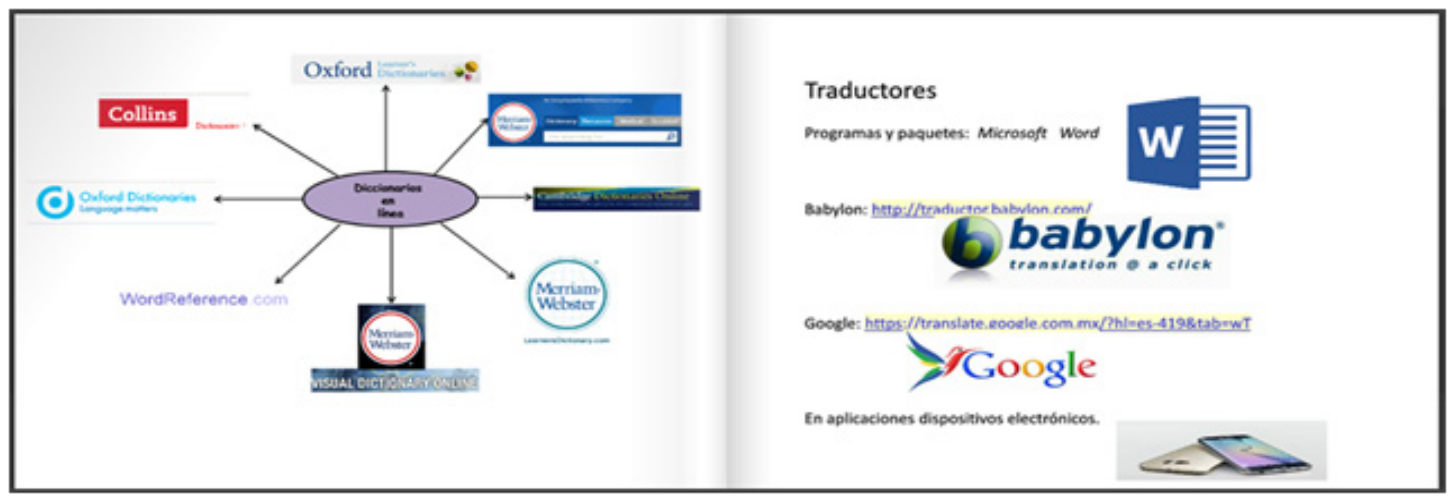

Figure I Menu of hyperlinks related to dictionaries and translators Hernández Rodríguez. ${ }^{4}$

Consult

https://www.flipsnack.com/ErnestoHernndezRodrguez/ cuadernillo-orientacione-para-traducir.html

The purpose of this material is to provide guidance on practices and strategies for translation, as well as explanations of the situations in which a literal, word by word, translation proceeds, and cases in which it is necessary to use other options to express something different in another language. These different kinds of translations involve contemplating language, contexts, and culture in a dynamic perspective. ${ }^{23-26}$ In the next activity, we remembered agreements and guidelines, discussed previously, to recommend texts in academic contexts. Students wrote the first bilingual version of the recommendation and shared it in the blog to receive feedback. Students received comments and suggestions about their writing. Then, they expressed orally their views on their performance and how they could improve them. The instruction for the first version was as follows.

\section{First version}

Use the processor Word to write your recommendation and then publish it in the blog.

\section{Consult:}

http://recomendacionesbilinguesmediateca.blogspot.mx/2015/11/ primera-version.html? view=sidebar

In the next part, students answered a questionnaire about this writing experience. The open questions provided the possibility to obtain information about printed, digital and online resources used by the students, their reflections on native and foreign languages, as well as their strategies for self-translation and revision in bilingual writing. Below we can read the aspects contemplated in this questionnaire:

Version 1:

Mention the query tools that you used to write this bilingual version

What knowledge did you use to write a bilingual text?
In Spanish:

In English:

Explain the strategies you used for your bilingual writing

After the feedback phase on the drafted bilingual text, students were asked to write a second version and they posted it in the blog.

\section{Instructions to write version 2}

Apply the spelling and grammar checker of the Word program and make changes you consider to improve your writing. Consider the observations and suggestions provided by your advisor, as well as resources reviewed in the "Booklet of guidelines on translation and language usage". Do not forget the agreements made about the characteristics of a text recommendation. Now do your best to write your bilingual writing.

The activity included considerations about text revision and editing strategies, in this case, about the Word processor to improve writing. Students commented on their experiences in revision and editing decisions with the aid of the Word processor and feedback from the counselor.

\section{Questions about version 2}

In what writing situations can the spelling and grammar corrector from the Word processor software help you to improve your writing?

After using this revision and correction tool, what modifications did you make in your writing?

What modifications did you make to your writing based on the adviser's observations and suggestions?

What difficulties did you face?

Students wrote the number of versions they considered necessary, received feedback and decided their improved final text. Then students were invited to share their recommendations in digital presentations, for example, PowerPoint or Prezi, to share their texts on the blog. Students who experienced doubts and difficulties to organize their 
presentations received specific counseling. The purpose of the final questionnaire was to have information for research purposes, related to opinions and assessments on performance, strategies in revision and editing, agreements about writing expectations, feedback received, consultation of booklets to support bilingual writing and management of native and foreign languages. These were the aspects considered.

Explain the steps you took to write a bilingual recommendation.

How did your knowledge of both languages help you to write?

Do you think that knowledge of Spanish can help English writing? Why?
Do you think that knowledge of English can help Spanish writing? Why?

The methodological procedure to systematize students' responses in the reflection questionnaires contemplated the database tool included in the blog. In this way, data was classified and stored in categories and inserted in formats according to items established in this research. For example, in the following Figure 2, we can observe a part of the generated database, corresponding to performances in second versions. The main categories of classification included drafting procedure, revision and editing. The proposed categories for each question and its answers were useful for the subsequent interpretative analysis.

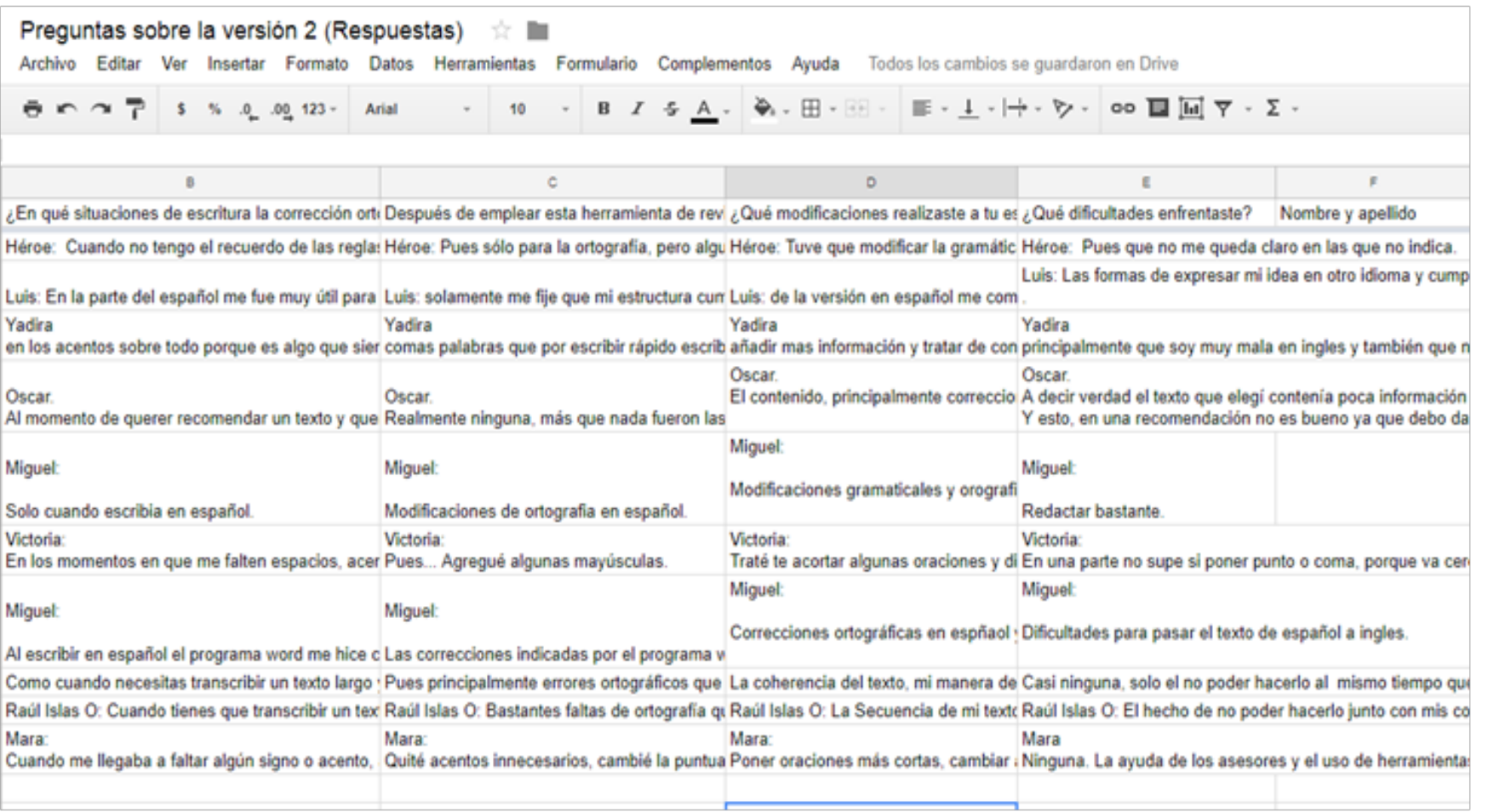

Figure 2 Some answers stored in the database. ${ }^{4}$

\section{Results}

In the phase of reading text recommendations, students expressed interest in bilingual writing. Here are some representative answers. Translation of students' responses respect their written intentionality in their expressions and language style. Here are some representative answers:

\section{Bilingual recommendation}

What can be the use of recommending texts to those who attend the language resource center?

Victoria: If as students we recommend masterpieces that we have enjoyed, we can help other students choose a text as well as encourage reading, not only in our school.

What can be the use of recommending a reading in a bilingual way? (Spanish-English)
Mara: *Practice translation, practice interpretation since many times if you give textual meaning to a sentence it does not make sense. *Make the reading accessible to people who do not speak the same language.

In what situations can we find bilingual texts? Mention some.

Oscar: When we are in important tourist places, there may be signs that are written in three different languages. Also in hospitals, museums, books in the language resource center, etc.

The previous activities about agreements to recommend texts in academic contexts and the process involved in writing them, helped us to recognize some expectations about text planning. The text read on the screen, discussion on how to recommend it in writing and socialization of criteria, led students to agreements for writing. Students contemplated interlocutors and expectations, related to standards of informativity, coherence, cohesion, situationality and adequacy, ${ }^{21}$ as we observe in the following examples. 
How would you write a bilingual recommendation of a text?

Yadira: You have to take into account to which public the text is directed to and try to convince them to read it. Writing should be easy and in a concrete way.

\section{What steps would you follow?}

Victoria: The first thing I would do is to have the bibliography of the text prepared. To continue, I would take fragments of the text that have been of my pleasure to quote them in the text as examples. Then I would make a brief review that would serve as material. Next, I would write my opinion on the text separately. Finally, I would group all the materials that I prepared to create a recommendation. I would organize and order them, take care of being brief and correct spelling and writing.

Consultation of manuals and sources related to information and language expressions in bilingual expressions facilitated writing and translation. Likewise, the Manual of guidelines on language usages was useful to contextualize lexicon and ways to adjust bilingual writing. However, students were not used to consulting practices included in this material. It was necessary an accompaniment procedure in advising so that students could get acquainted with textual resources, possibilities of intertextuality through links to access options of information, mainly, dictionaries and translators in contextualized ways to adjust and achieve adequate bilingual writing. Students also experienced difficulties to contextualize writing through the Word corrector software, applied to each language, mainly for accentuation, in Spanish, grammar and punctuation, that is, aspects related to standards of coherence, cohesion and textual adequacy. ${ }^{21}$ Therefore, emphasis in counseling was recognition and adaptation to multimedia printed and online possibilities in textual revision and edition in the bilingual recommendation of texts.

Students experienced different performances when trying to identify and start using varieties of printed, digital and online resources. They expressed reflections about the management of native and foreign languages, as well as their self-translation and textual revision strategies in writing. Results show a preference for online dictionaries and translators, grammar, lexical selection and coherence in English, basic knowledge of Spanish and correct translation. In terms of strategies, they emphasized lexical adequacy in language context to achieve translation, ways to motivate readers and management of online consultation sources. Below we present representative examples of students' considerations.

About version 1

Mention query tools that you used to write this bilingual version.

Oscar: I used a dictionary that I found in the language resource center to support me and to know the meaning and translation of certain words I did not know. As well as the translator included in WORD software to support me in spelling mistakes.

Miguel: Cambridge Dictionaries online, oxford learners dictionaries and Google translator.

What knowledge did you use to write the bilingual text?

In Spanish:

Victoria: What I know about writing, that is, about commas, punctuation. Not using too many links, not repeating a word a lot.
Also what the professor told us about being brief, of course, and not saying more or less than what is needed.

Oscar: Well, previous knowledge since high school taught us the language that somehow facilitated writing. The advice of the professor was important.

In English:

Victoria: Most of the words I already knew, as well as structures, basically. I did not need to look for too much help in resources that I consulted.

Well, what language is, which is to use the auxiliaries and verbal tenses, and to omit some words that we use here and there are unnecessary.

Yadira: Trying to make sure that what I was trying to translate had consistency and not to make bad translations of knowledge that I have acquired in courses.

Explain the strategies you used for your bilingual writing:

Victoria: I tried to respect brevity and the idea of the text in Spanish, as well as using appropriate terms since sometimes they vary depending on the context, and as always, there are several words that can be left but you always have to look for the best one.

Miguel: I translated the text from Spanish to English using the help of dictionaries like Cambridge online dictionaries.

Regarding version 2, students expressed the need to contextualize translations obtained through online translators and Word processor software corrections. They highlighted the importance of grammar and orthographic correction, accentuation in Spanish, punctuation, lexical selection, translation and difficulties in both languages.

About version 2

In what writing situations can spelling and grammar corrections provided by Word software help you improve your writing?

Victoria: At times when I lack spaces, accents or there is no agreement between subjects, pronouns and verbs.

After using this revision and correction tool, what modifications did you make to your writing?

Yadira: comas, capital letters, and words that, because of my fast writing, I wrote incorrectly.

Mara: I removed unnecessary accents, I changed my punctuation.

What modifications did you make to your writing based on the adviser's observations and suggestions?

Miguel: Grammar and spelling modifications in English and Spanish, and suggestions about aspects to make a good recommendation of a text.

Mara: Write shorter sentences, change some words that were better suited to the text, add subjects where they were needed.

What difficulties did you experience?

Victoria: In one part I did not know whether to write a period or a comma, because it is close to an exclamation point, and both English and Spanish were complicated. 


\section{Miguel: Difficulties to translate from Spanish to English.}

In the following example, we observed the recommendation of a Mexican pre-Hispanic poem about the women of Chalco, ${ }^{27}$ and the interaction with the adviser on the blog. Subsequently, this feedback was complemented in personal interaction in the Language resource center. Transcription of the texts respects students' written expressions in both languages, without making corrections on spelling, grammar, word segmentation and accentuation.

\section{Yadira}

\section{First version}

Spanish

Recomendación de la lectura las mujeres de chalco

Este poema se encuentra en el libro cantos y crónicas del México antiguo junto con otros muy buenos poemas de la época, se desarrolla en la época prehispánica y es un poema erótico esto es lo que lo hace especial y lo que lo conecta con cualquier época porque es algo que no ha dejado de existir.

\section{English}

Recommended reading women chalco

This poem is in the book songs and chronicles of ancient Mexico along with other very good poems of the time, is developed in ancient times and is an erotic poem this is what makes it special and what connects to any time because it is something that no longer exist.

Feedback

\section{Hello Yadira}

About your Spanish version: The way you recommended this poem is impersonal. Try to include phrases and verbs that allow the reader to frame your recommendation in the time you describe. In this way you can generate more interest in this reading. Do not forget to indicate who the author of the poem is. Your opinion about this poem does not sound convincing: you mention that it is special because it belongs to the pre-Hispanic era. Explain this information according to your your perspective and preference. What will the reader find when reading it?

About your English version: I suggest you write a more attractive title that arouses interest in this poem. The title "Recommended reading women chalco" is confusing and grammatically incorrect. Be sure to use the preposition from "women from chalco", and noun in the phrase"recommendation of a text", instead of "recommended reading". I suggest you review once again the notes in the section "Orientations on translation and language usage" in this blog. You provide information, but you miss your points of view to recommend the text. Try to convince readers. Remember that it is not necessary to translate directly, there are other ways to communicate the same idea without having to translate it so directly. In the sentence "is developed in ancient" you omitted the subject. Do not forget that in English it is necessary to mention the subject of the sentence. Try to include shorter sentences and separate them with commas and periods.

\section{Second version}

Spanish

Recomendación de la lectura las mujeres de chalco
Este poema se encuentra en el libro cantos y crónicas del México antiguo junto con otros muy buenos poemas de la época es un poema bastante interesante que me gustó mucho, se desarrolla en la época prehispánica, es erótico algo que lo hace especial y lo que lo conecta con cualquier época porque es algo que no ha dejado de existir.

\section{English}

\section{Recommendation Reading Women Chalco}

This poem is in the book Cantos and chronicles of ancient Mexico with Other very good poems Epoch is a very interesting poem I really liked, takes place in ancient times, it is an erotic something makes it special and what connect to anytime because it is something that has not ceased to exist.

\section{Third version}

\section{Spanish}

\section{Recomendación de la lectura las mujeres de chalco}

Este poema se encuentra en el libro cantos y crónicas del México antiguo junto con otros muy buenos poemas de la época es un poema nahuatl cuecuechcuícatl "cantos de cosquilleo o festivos", me gustó mucho, se desarrolla ya que es de época prehispánica, también es erótico algo que lo hace especial y lo que lo conecta con cualquier época porque es algo que no ha dejado de existir

\section{English}

Recommendation of the Reading Women Chalco This poem is in the book songs and chronicles of ancient Mexico, along with other very good poems of the time is a Nahuatl poem cuecuechcuícatl" songs tingling or holidays," I really liked it develops because it is pre-Hispanic times, it is also erotic something that makes it special and what connects it to any time because it is something that has not ceased to exist

In her last version, Yadira was able to provide accurate information about the poem, she solved most grammatical issues, highlighted what she liked about the text, however, she had difficulties in expressing her opinions explicitly and taking into account potential readers directly. The next representative example presents a final version of a book recommendation about Sor Juana Ines de la Cruz and her sonnets (Hernandez Rodriguez \& Rodriguez Nava, 2007) and the presentations made by two students to share their bilingual texts.

\section{Casandra's final version}

\section{Spanish}

¿Te has sentido como de otra época o como si fueras de otro mundo? Juana de Asbaje, mejor conocida como Sor Juana Inés de la Cruz, representante de más de un género literario: Drama, teatro, poesía y etcétera, ella se sentía exactamente igual, el siglo XVII no estaba listo para ella. Te invito a conocer su apasionante mundo, su constante lucha por el conocimiento y su amor a las letras en el libro: "Para leer... Los sonetos de Sor Juana" de los autores Rodríguez Olga y Hernández Ernesto; en donde no sólo encontrarás su historia, tendrás el placer de encontrar una antología de sus sonetos con los que podrías sentirte identificado. Por ejemplo: "Prosigue el mismo asunto, y determina que prevalezca la razón contra el gusto" para amores no correspondidos; ¿Mueres de amor? "Efecto muy penoso de amor, y que no por grandes se igualan con las prendas de quien le causa" es para ti. ¡Busca tu soneto! 


\section{English}

Have you ever felt as if you came from another time or world? Juana de Abase, better known as Sor Juana Ines de la Cruz, represents more than a literary genre: Drama, theater, poetry and so on, she felt exactly the same, the seventeenth century was not ready for her. I invite you to know her exciting world, her constant struggle for knowledge and her love for literature in the book: "Para leer... Sonetos de Sor Juana" written by Olga Rodriguez and Ernesto Hernandez; where you not only find her story, you have the pleasure of meeting an anthology of her sonnets with which you may feel identified. For example, "Prosigue el mismo asunto, y determina que prevalezca la razón contra el gusto" to unrequited love; Do you die of love? "Efecto muy penoso de amor, y que no por grandes se igualan con las prendas de quien le causa" It is for you. Find your sonnet!

\section{Casandra s presentation}

Consult: $\quad$ https://prezi.com/3uo5yrufogim/quotpara-leer-lossonetos-de-sor-juana/

Victoria's presentation

Consult: campaign $=$ share\&utm_medium $=$ copy

In the final questionnaire, we can appreciate students' awareness in performance progress in managing resources and information in the blog as aids to develop and improve bilingual writing to recommend texts. In self-translation practices, students considered the text in Spanish as the original one to be translated with multiple strategies and multimedia materials. They recognized the need to adjust writing and translation in both languages. Most of them expressed that knowledge of both languages was fundamental for bilingual writing, nevertheless, they emphasized that Spanish could serve them to write in English, but that knowledge of this foreign language would not be useful to improve their written Spanish. Let's review some answers.

1. Explain the steps you took to write your bilingual recommendation of the text you chose.

Victoria: First, I tried to create a good structure in Spanish taking into account considerations and suggestions already established for this kind of writing: brevity, be interesting, quote important fragments, give all necessary data from the text, provide some examples, etc. I used some dictionaries and translators to create the English version with the same structure, however, I had to correct some parts that I did not pay enough attention to. Later, I still had to make improvements in Spanish writing, which meant also modifying my English version and reducing the size of the sentences so that it was easier to read. Finally, I had to fine-tune small details of missing words, cut out a few things that were left over, small details, and then I ended the final version.

Miguel: First I reviewed the criteria to recommend a text, I continued reviewing resources for writing in English and opening these pages of online dictionaries, I translated words and with the observations made by the teacher I corrected my mistakes and finished the recommendation.

2. How did your knowledge of both languages help you to write?

Victoria: In Spanish, knowledge of several words helps, as well as spelling knowledge and my very basic that I also know about writing, in English what I have already mentioned before.

Yadira: I think that from the moment you start writing, knowledge is being applied since spelling requires the way you write, and also the fact that you have read the text to be able to recommend it, in English I simply translated the best I could

3. Do you think that knowledge of Spanish can help English writing? Why?

Victoria: Yes. Because you can not handle another language well if you do not know yours properly.

Yadira: Yes, because even though they are different languages, sentences and the sense in which they are going, for example, you can't always write a verb in infinitive form, regardless of what subject you are talking about.

Miguel: No. Since they are quite different languages, Spanish is much more complete.

4. Do you think that knowledge of English can help Spanish writing? Why?

Victoria. No. Because the one I have is very basic, so the original text is always in Spanish, this means that the English text is based on the other, almost unchanged.

Oscar: I do not think so, because Spanish has more words that do not need to be translated into English to be understood.

Mara: No. Since they are very different languages and because they are not equal, it does not help to know one to write in the other.

Students expressed interest in grammar, spelling, punctuation, accentuation and vocabulary in Spanish. In English, they emphasized grammar, verb tenses, auxiliaries, and lexical selections to translate. As for strategies, they mentioned considerations and agreements about expectations to write bilingual recommendation, practices and translation resources. They highlighted revision procedures with the Word software editor and modifications in grammar and spelling, but did not contemplate situations in which this resource does not solve aspects of adequacy in lexical selection. So, during personal feedback, it was fundamental to emphasize that this word processor has to be used and complemented with the support of knowledge, consultations with other sources, contextualized revision and edition practices.

\section{Discussion}

This bilingual writing experience allowed us to realize that students needed to adapt and contextualize textual practices, corresponding to printed and online multimedia resources, in interactive consultation. In text writing and editing practices, online interaction required to be complemented with personal feedback. Therefore, this methodology provided different types of interaction and textuality practices. Responses in questionnaires fostered reflection on performance. The option of databases offered by the blog was essential to create classification and analysis categories. Manifestations about considerations and agreements on how to write bilingual recommendations of a text encouraged reflections on textuality criteria and performance expectations, related to textuality standards, ${ }^{21}$ awareness about interlocutors and their expectations ${ }^{28}$ and intentionality. ${ }^{29}$ There were limitations with students who, initially, did not have prior knowledge or disposition to share information or reflections about performances in interactions. In these situations, the proposal of elicitation in this research helped students to express points of view and considerations about performance..$^{20}$

Contextualized practices with query sources, online translators and the Word processor corrector software provided useful tools and activities to identify the advantages and limitations of these resources, 
and the ways to use them appropriately through alternative strategies in bilingual writing. Reflection questions on textual revision and edition, as a result of feedback and consultation with the Word software editor, promoted awareness of skills and performance regulation. ${ }^{30}$

The contribution of this proposal is a reflexive approach to diverse practices and sources of textuality in bilingual writing. However, in different environments we can find limitations to access multimedia equipment, and printed and online materials, so teachers need to adapt and take advantage of existing possibilities.

Feedback and reflection in questionnaires helped students recognize difficulties in textual and grammar structures and they experienced revision and editing practices to improve writing performances. In this way, students could develop strategies to adjust grammar, lexical adequacy, coherence, contextualized bilingual expression and management of multimedia resources. Opportunities to receive feedback about performances in both languages helped students realize the importance of reflection in self-translation.

Feedback experience through publication of comments in the blog favored personal and online interaction. Students could take into account suggestions in interactions with interlocutors in reading ${ }^{24}$ and writing. ${ }^{28}$ This type of interaction corresponds to interpersonal communication perspectives ${ }^{31}$ on the characteristics offered by digital reading for communication, regardless of time and distance. ${ }^{15}$ Subsequent oral counseling provided options to broaden feedback for those who had difficulties in online interaction. Students tried to strengthen written performance through resources for bilingual writing and highlighted the different possibilities they offer for learning. Reflexive bilingual written practices led students to be aware of linguistic difficulties so they could experience compensatory strategies, as a result of performance self-regulation ${ }^{32,33}$ in printed and digital modalities. ${ }^{34}$

Yadira's performance is a representative example of partial advance in revision and editing to try to improve writing in terms of textuality standards ${ }^{21}$ in cohesion, coherence, informativity and intertextuality, as well as self-translation attempts to adjust the bilingual version to fit language resources and content in both languages. Yadira's intentionality was similar to most students' difficulties in performance to represent interlocutors textually to share points of view to convince them about comments of a text.

We also observed textual interpretations in students who tried to clarify information for readers. ${ }^{29}$ In the final questionnaire, the idea that knowledge of Spanish was useful for writing in English is due to the fact that the students first contemplated writing in their mother tongue. This language was the main reference to try self-translation and then they experienced different strategies to adjust grammar, vocabulary and contextual usages in both languages to write a bilingual version. Spanish was the initial knowledge to regulate writing.

The socialization of bilingual versions in digital presentations, such as Powerpoint or Prezi, enabled motivation to share final corrected and modified texts and considerations about potential readers' reactions. We can observe intentionality to take into account agreements and suggestions, with emphasis on grammar aspects and lexical selections. Students could realize the importance of feedback in online modalities and in a personal way in counseling, as well as reflections on performance, multimedia resources and strategies in bilingual writing. ${ }^{35-39}$

\section{Conclusion}

Methodological practices in bilingual writing of literary text recommendations, with the support of printed and online multimedia resources and personal counseling, provide useful criteria revision, textual editing development and self-translation strategies in bilingual writing. This proposal can be adapted in different contexts where personal advice is contemplated with different options of multimedia materials for writing. In the case of online education, results in this research prevent us from taking for granted that students can, initially, interact with multimedia and online resources, due to difficulties faced in this writing experience. In this situation, it is essential to promote dialogical and interactive situations. In this way, we can develop written practices in printed and online communications and access to sources of consultations to use them with the purpose to improve bilingual writing.

Reflection questionnaires encourage awareness of expectations about performance and criteria related to self-translation, textuality standards, intentionality and interlocutor representation. The experience carried out in this research exhibits the need to explore and gradually incorporate reading and writing habits associated to interactivity and intertextuality through feedback, with multiple manifestations of textualities: printed, digital, online and interactions in advice for bilingual writing. The proposal allows enrichment in practices, habits and textual repertoires in different formats and modalities in written communication.

Whenever students experience difficulties in bilingual expressions, contextualized written activities foster expectations and agreements in this kind of academic writing, revision and edition practices to promote self-regulation, as a result of personal and online feedback to improve texts. Likewise, establishing relations between Spanish and English in linguistic performances is an approach that facilitates adjustment and modifications of written expressions in both languages. This situation is fundamental in language teaching since performance reflexivity and experimenting strategies are fundamental to achieve critical improvement in bilingual writing.

Intentionality in attempts to improve bilingual versions enabled students to experience a reflexive performance, self-regulation, and adaptation to multimedia sources of printed or online textual modalities. For example, in improving writing in second versions, it was important to manage language software, such as online translators and word processors, in contextualized bilingual usages. Students needed support to expand their knowledge, access to multimedia collections and their linguistic repertoires in order to enrich their options for bilingual revision and editing. Therefore, this research provides a contextualized perspective of gradual assessment for bilingual writing during feedback, which can be implemented and adapted in different educational environments. Teaching and elicitation methods, classification categories and systematization of information procedures provide tools for interaction and textual characterization, which can be applied, with appropriate adaptations, in future research on students' considerations and expectations on bilingual written performance.

\section{Acknowledgments}

None.

\section{Conflicts of interest}

The author declares there is no conflict of interest.

\section{References}

1. Pegenaute L. La traducción como herramienta didáctica. Contextos. 1996;14(27-28):107-125. 
2. Nord Ch. Text analysis in translation: Theory, methodology and didactic application of a model for translation-oriented text analysis. Ámsterdam: Rodopi. 1991.

3. Fredholm K. Online translation use in spanish as a foreign language essay writing: effects on fluency, complexity and accuracy". Revista Nebrija de lingüística aplicada. 2015;8:1-18.

4. Hernández Rodríguez E. Intencionalidad y desempeño en la redacción bilingüe, español-inglés, de reseñas bibliográficas en bachillerato. Signos lingüísticos. 2015;11(21/22):36-69.

5. Popovič A. Dictionary for the analysis of literary translation. Edmonton: Department of Comparative Literature. University of Alberta. 1976.

6. Cocco S. Lost in translation. Testi e culture allo specchio. AnnalSS. 2009;6:103-118.

7. Grutman R, Van Bolderen T. Self translation. En S Berman et al., editors. A companion to translation studies, West Sussex: Wiley-Blackwell. 2014. p. 323-332.

8. Petrucă I. Self-translation, communication bridge between cultures. In I Boldea editor. The proceedings of the international conference: literature, discourse and multicultural dialogue. Section language and discourse. Targu-Mures: Archipelag XX Press. 2013. p. 759-762.

9. Jung V. English-German self-Translation of academic texts and its relevance for translation theory and practice. Oxford: Peter Lang. 2002.

10. Whitman L. The effectiveness of interactivity in computer-based instructional diagrams. In JA Jacko editor. Human Computer Interaction. 2009;2:889-908

11. Coyle JR, Thorson E. The effects of progressive levels of interactivity and vividness in web marketing sites. Journal of Advertising. 2001;30(3):1328.

12. Mayer ER. Cognitive theory and the design of multimedia instruction: An example of the two-way street between cognition and instruction. New directions for teaching and learning. 2010;89:55-71.

13. Fabre-Cols C. Réécrire à l'école et au collège: De l'analyse des brouillons à 1' écriture accompagnée. Issy-les-Moulineaux: ESF éditeur. 2002.

14. Macklin T. Compassionate Writing Response: Using dialogic feedback to encourage student voice in the first-year composition classroom. Journal of response to writing. 2016;2(2):88-105.

15. Cordón JA. La lectura en el entorno digital: nuevas materialidades y prácticas discursivas. Revista chilena de literatura. 2016;94:5-38.

16. García LA. Dimensiones de análisis de los blogs. En S. Martínez y E Lozano. Blogs, bloggers, blogósfera: una visión multidisciplinaria. México: Universidad Iberoamericana. 2010. p. 75-86.

17. Álvarez G. Las nuevas tecnologías en el contexto universitario: sobre el uso de blogs para desarrollar las habilidades de lectoescritura de los estudiantes. Revista de universidad y sociedad del conocimiento. 2012;9(2):3-17.

18. Reyes Angona S, Fernández-Cárdenas JM, Martínez Martínez R. Comunidades de blogs para la escritura académica en la enseñanza superior: un caso de innovación educativa en México. Revista Mexicana de Investigación Educativa. 2013;18(57):507-535.
19. Gass SM, Mackey A. Data elicitation for second and foreign language research. Mahwah: Lawrence Erlbaum Associates. 2007.

20. Hyland K. Methods and methodologies in second language writing research. System. 2016;59:116-125.

21. De Beugrande R, Dressler W. Introducción a la lingüística del texto. Barcelona: Ariel-Lingüística. 1997.

22. Paz O. Traducción, literatura y literacidad. Barcelona: Tusquets. 1971.

23. Nida E. Contexts in translating. Ámsterdam/Philadelphia: John Benjamins Publishing Company. 2001.

24. Eco U. Decir casi lo mismo: experiencias de traducción. Barcelona: Lumen. 2008

25. Hill R. Nasreddin ten stories. Génova: Black Cat. 2007.

26. Bassnett S. Writing and translating. In: S Bassnett et al., editors. The translator as writer. Londres: Continuum. 2006. p. 172-182.

27. León-Portilla M. Cantos y crónicas del México Antiguo. México: Promolibros. 1983. p. 1-157.

28. Hyland K. Metadiscourse: Exploring interaction in writing. London/New York: Continuum. 2005

29. Beuchot M. Elementos esenciales de una hermenéutica analógica. Diánoia. 2015;60(74):127-145.

30. Wenden A. Helping language learners think about learning. In R Rossner editor. ELT Journal. An international journal for teachers of English to speakers of other languages. 1986; 40(1):161-175.

31. Berthon P, Pitt L, Watson RT. Re-surfing W3: Research perspectives on marketing communication and buyer behavior on the worldwide web. International journal of advertising. 1996;15(9):287-301.

32. Oxford R. Language learning strategies: what every teacher should know. Boston: Heinle \& Heinle Publisher. 1990. p. 1-25.

33. Torre Puente JC. Aprender a pensar y pensar para aprender. Madrid: Narcea. 1992

34. Flores-Carrasco PG, Díaz-Mujica A, Lagos-Herrera IE. Comprensión de textos en soporte digital e impreso y autorregulación del aprendizaje en grupos universitarios de estudiantes de educación. Revista electrónica Educare. 2017;21(1):1-17.

35. Bausela Herreras E. Relación entre autorregulación y autoconocimiento de la escritura con la coherencia y productividad de un texto. Cuestiones pedagógicas. 2007;18:257-270

36. Eco U. Lector in fabula: la cooperación interactiva en el texto narrativo. Barcelona: Lumen. 1979. p. 1-329.

37. Hernández Rodríguez E, Reyes Galicia E. Cuadernillo de recursos para la redacción bilingüe. Blog de apoyo pra la redacción bilingüe. 2015.

38. Hernández Rodríguez E, Rodríguez Nava OL. Para leer los sonetos de Sor Juana. México: Limusa. 2007.

39. Martínez LM. Experimentación académica con blogs. En S. Martínez y E Lozano. Blogs, bloggers, blogósfera: una visión multidisciplinaria. México: Universidad Iberoamericana. 2010. p. 125-131. 